University of Nebraska - Lincoln

DigitalCommons@University of Nebraska - Lincoln

Interaction Between Bunk Management and Monensin

Concentration on Finishing Performance, Feeding Behavior, and Ruminal Metabolism During an Acidosis Challenge with Feedlot Cattle

\author{
Galen Erickson \\ University of Nebraska-Lincoln, gerickson4@unl.edu \\ C. T. Milton \\ University of Nebraska-Lincoln \\ K. C. Fanning \\ University of Nebraska-Lincoln \\ R. J. Cooper \\ University of Nebraska-Lincoln \\ R. S. Swingle \\ Cactus Research, Ltd., Amarillo, TX \\ See next page for additional authors \\ Follow this and additional works at: https://digitalcommons.unl.edu/animalscifacpub \\ Part of the Animal Sciences Commons
}

Erickson, Galen; Milton, C. T.; Fanning, K. C.; Cooper, R. J.; Swingle, R. S.; Parrott, J. C.; Vogel, G.; and Klopfenstein, Terry, "Interaction Between Bunk Management and Monensin Concentration on Finishing Performance, Feeding Behavior, and Ruminal Metabolism During an Acidosis Challenge with Feedlot Cattle" (2003). Faculty Papers and Publications in Animal Science. 456.

https://digitalcommons.unl.edu/animalscifacpub/456

This Article is brought to you for free and open access by the Animal Science Department at DigitalCommons@University of Nebraska - Lincoln. It has been accepted for inclusion in Faculty Papers and Publications in Animal Science by an authorized administrator of DigitalCommons@University of Nebraska - Lincoln. 


\section{Authors}

Galen Erickson, C. T. Milton, K. C. Fanning, R. J. Cooper, R. S. Swingle, J. C. Parrott, G. Vogel, and Terry Klopfenstein 


\title{
Interaction between bunk management and monensin concentration on finishing performance, feeding behavior, and ruminal metabolism during an acidosis challenge with feedlot cattle ${ }^{1}$
}

\author{
G. E. Erickson*2, C. T. Milton*3, K. C. Fanning*, R. J. Cooper*, R. S. Swingle ${ }^{*}$, \\ J. C. Parrott $\ddagger^{4}$, G. Vogel $\ddagger^{5}$, and T. J. Klopfenstein* \\ *Department of Animal Science, University of Nebraska, Lincoln 68583-0908; †Cactus Research, Ltd., \\ Amarillo, TX 79116; and $\ddagger$ Elanco Animal Health, Indianapolis, IN 46285
}

\begin{abstract}
Two commercial feedlot experiments and a metabolism study were conducted to evaluate the effects of monensin concentrations and bunk management strategies on performance, feed intake, and ruminal metabolism. In the feedlot experiments, 1,793 and 1,615 steers were used in Exp. 1 and 2, respectively, in 18 pens for each experiment (six pens/treatment). Three treatments were evaluated: 1 ) ad libitum bunk management with $28.6 \mathrm{mg} / \mathrm{kg}$ monensin and clean bunk management strategies with either 2) 28.6 or 3) $36.3 \mathrm{mg} /$ $\mathrm{kg}$ monensin. In both experiments, 54 to $59 \%$ of the clean bunk pens were clean at targeted clean time, or 2200 , compared with 24 to $28 \%$ of the ad libitum pens. However, only $13 \%$ of the pens were clean by 2000 in Exp. 1 (summer), whereas $44 \%$ of the pens in Exp. 2 (winter) were clean by 2000. In Exp. 1, bunk management and monensin concentration did not affect carcass-adjusted performance. In Exp. 2, steers fed ad libitum had greater DMI $(P<0.01)$ and carcass-adjusted ADG $(P<0.01)$ but feed efficiency $(P>0.13)$ similar to that of clean bunk-fed steers. Monensin concentration had no effect on carcass-adjusted performance $(P>0.20)$
\end{abstract}

in either experiment. A metabolism experiment was conducted with eight fistulated steers in a replicated $4 \times 4$ Latin square acidosis challenge experiment. An acidosis challenge was imposed by feeding $125 \%$ of the previous day's DMI, $4 \mathrm{~h}$ later than normal. Treatments consisted of monensin concentrations $(\mathrm{mg} / \mathrm{kg})$ of $0,36.7$, 48.9 , or 36.7 until challenged and switched to 48.9 on the challenge day and $4 \mathrm{~d}$ following. Each replicate of the Latin square was managed with separate bunk management strategies (clean bunk or ad libitum). Feeding any concentration of monensin increased number of meals and decreased DMI rate $(\% / \mathrm{h})(P<0.12)$ for the $4 \mathrm{~d}$ following the acidosis challenge. Meal size, $\mathrm{pH}$ change, and $\mathrm{pH}$ variance were lower $(P<0.10)$ for steers fed monensin with clean bunk management. However, no monensin effect was observed for steers fed ad libitum. Bunk management strategy has the potential to decrease DMI and ADG when steers managed on a clean bunk program are restricted relative to traditional, ad libitum bunk programs. Monensin helps control intake patterns for individuals, but increasing concentration above currently approved levels in this study seemed to have little effect.

Key Words: Acidosis, Cattle Feeding, Feed Intake, Feedlots, Monensin

(C2003 American Society of Animal Science. All rights reserved.

J. Anim. Sci. 2003. 81:2869-2879

\section{Introduction}

Bunk management is of critical importance in the overall management of feedlot cattle. A goal of bunk

\footnotetext{
${ }^{1}$ Published with the approval of the director as Paper No. 13819, Journal Ser., Nebraska Agric. Res. Div.

${ }^{2}$ Correspondence: C220 Animal Sciences (phone: 402 472-6402; fax: 402 472-6362; E-mail: gerickson4@unl.edu).

${ }^{3}$ Present address: Midwest PMS, 4615 Deva Rd., Grand Island, NE 68801.

${ }^{4}$ Address: P.O. Box 416, Council Bluffs, IA 51502.

${ }^{5}$ Address: 9011 Dove Rd., Canyon, TX 79015.

Received September 11, 2002.

Accepted August 4, 2003.
}

management is to provide the correct amount of feed to the correct pen at the desired time daily (Pritchard and Bruns, 2003). Traditional bunk management meant continuous access to feed in order to achieve ad libitum intake. Many nutritionists and cattle feeders have recently adopted "clean bunk" feeding programs. The goal of clean bunk management is for all feed delivered to a pen to be consumed daily, with bunks being empty for a certain period of time prior to the next feeding, without restricting DMI compared to traditional bunk management (Pritchard and Bruns, 2003). However, a potential risk of clean bunk management is that DMI will be restricted to certain individuals within a pen, thus increasing the chance of those re- 
stricted cattle consuming more feed at a more rapid rate. Consumption of high-grain diets in large amounts and at rapid rates may increase the risk of subacute acidosis, intake variation, or digestive disorders (Fulton et al., 1979; Stock et al., 1990).

Monensin (Rumensin; Elanco Animal Health, Greenfield, IN) is an ionophore commonly fed to feedlot cattle. In addition to improving feed efficiency (Richardson et al., 1976; Goodrich et al., 1984), monensin reduces feed intake variation (Burrin et al., 1988; Stock et al., 1995) and increases the ruminal $\mathrm{pH}$ of cattle fed high-grain diets (Nagaraja et al., 1981; Burrin and Britton, 1986). If clean bunk management systems impose a greater risk of digestive disturbances than traditional ad libitum approaches, then increasing dietary monensin concentration may be beneficial in clean bunk management programs.

The objectives of these experiments were to compare traditional bunk management and clean bunk management strategies on steer performance, feeding behavior, and ruminal fermentation, and to determine whether dietary monensin concentration alters cattle and ruminal responses to clean bunk management systems.

\section{Materials and Methods}

\section{Feedlot Performance}

In Exp. 1, 1,793 medium large-frame mixed-breed steers (261 kg initial BW) were used in a randomized complete block design with three treatments and six pens per treatment. Blocks were pen replicate (one to six), with treatments assigned randomly to blocks of three pens, with six total blocks. Steers were received at a commercial research facility on April 25 and April 28, 1998, from Benjamin, TX. From receipt until allotment, cattle were maintained in holding pens and fed a standard moderate-concentrate receiving diet plus loose, long-stem alfalfa hay and allowed ad libitum access to drinking water. On d 0 (April 29, 1998), steers were allotted into groups of no more than 10 animals at a time into 18 pens. There were 80 to 120 steers per pen, adjusted to provide approximately $23 \mathrm{~cm}$ of linear bunk space and $14 \mathrm{~m}^{2}$ of pen space per animal.

In Exp. 2, 1,615 medium large-frame mixed-breed steers (304 kg initial BW) were used in a randomized complete block design similar to Exp. 1, with three treatments and six pens per treatment. Steers were received at the research facility from November 3 through November 8, 1998, from Ft. Stockton, TX. Upon receipt, cattle were handled as described above and on d 0 (November 10, 1998) were fed in the same 18 pens used in Exp. 1. A winter stocking rate was used, which provided $25 \mathrm{~cm}$ of feed bunk space and $15 \mathrm{~m}^{2}$ of pen space per animal. Pen counts ranged from 72 to 104 .

Following each allotment of animals into feedlot pens, each pen was group-weighed to determine average initial weight, and subsequently processed. Each steer was individually identified; implanted with Ralgro (Scher-
ing-Plough, Inc., Union, NJ); vaccinated with an IBRLeptospira modified live vaccine and a seven-way clostridial bacterin-toxoid (Vision 7, Intervet, Millsboro, $\mathrm{DE}$ ); drenched with a dispersible liquid containing 1,000,000 IU Vitamin A and 200,000 IU Vitamin E (Rovimix, Roche Vitamins, Inc.) and treated for internal and external parasites (Ivomec Plus, Merial Inc., Duluth, GA, in Exp. 1; Dectomax, Pfizer Animal Health Inc., Exton, PA, in Exp. 2.)

Steers were reimplanted with Revalor-S (Intervet) on d 75 and 76 (Exp. 1) or d 76 and 77 (Exp. 2). Each steer received a booster vaccination of seven-way clostridial bacterin-toxoid (Vision 7, Intervet) at reimplantation. Cattle were exposed to terminal implant for 112 $\mathrm{d}$ in Exp. 1 and $93 \mathrm{~d}$ in Exp. 2. Steers were fed 187 and $169 \mathrm{~d}$ for Exp. 1 and 2, respectively. Pen weights were taken and pencil shrunk $4 \%$ to determine average final live weight for each pen. Steers were harvested and carcass data collected by trained personnel at a commercial abattoir located in Amarillo, TX. Carcass-adjusted final live weights were calculated for each pen by multiplying the actual final shrunk live weight by the pen dressing percentage divided by the experiment average dressing percent.

Treatments were as follows: 1 ) traditional, ad libitum bunk management program with monensin fed at 28.6 $\mathrm{mg} / \mathrm{kg}$ of dietary DM, which equates to $26 \mathrm{~g} / \mathrm{ton}$ (ADLIB-26); 2) clean bunk program with monensin fed at $28.6 \mathrm{mg} / \mathrm{kg}$ (CB-26); and 3) clean bunk program with monensin fed at $36.3 \mathrm{mg} / \mathrm{kg}$ of $\mathrm{DM}$, which equates to $33 \mathrm{~g} / \mathrm{ton}$ (CB-33). All diets were formulated with 9.9 $\mathrm{mg}$ of Tylan (Elanco Animal Health) per kilogram of dietary DM. Composition of the finishing diets for Exp. 1 and 2 are provided in Table 1. Three step-diets containing approximately 36,28 , and $20 \%$ forage (DM basis), respectively, were used to adapt steers to the finishing diets. Steers were fully adapted to the finishing diets on $d 19$ in both experiments.

Cattle were fed two times daily while on the finisher diet. The first feeding began at 0600, and the second feeding began at 1300 . Feed bunks were targeted to be empty of feed by 2200 for the clean-bunk program and by 0600 for the traditional bunk management program. Theoretically, steers on the clean bunk program had approximately $8 \mathrm{~h}$ less exposure to feed each day than those fed using the traditional bunk management approach. Feed bunks were visually scored by estimating the amount of feed remaining at approximately 2000, 2200,0000 , and 0600 with a numeric score assigned at each viewing: 1) slick, no residual crumbs or fines, licked clean; 2) minimal amount of residual crumbs and fines (i.e., less than $11 \mathrm{~kg}$ ); 3) small amount of residual feed (i.e., approximately 11 to $27 \mathrm{~kg}$ ); 4) moderate amount of residual feed (i.e., 27 to $45 \mathrm{~kg}$ ); and 5) large amount of residual feed (i.e., greater than $45 \mathrm{~kg}$ ).

Feed calls were adjusted for the traditional bunk management approach based on visual readings at 2000,0000 , and 0600. If a bunk score of 2 or greater was recorded at 2000 , feed amounts were increased by 
Table 1. Average composition of finishing diets used in both commercial feedlot studies (Exp. 1 and 2) evaluating monensin concentration and bunk management strategy (DM basis)

\begin{tabular}{lc}
\hline \hline Item & \% of dietary DM \\
\hline Ingredients & \\
Steam-flaked grain ${ }^{\mathrm{a}}$ & 56.8 \\
High-moisture corn & 18.8 \\
Roughage & 11.4 \\
Animal fat & 3.5 \\
Molasses & 1.8 \\
Pelleted supplement & 7.7 \\
Chemical composition & \\
NE $E_{\mathrm{m}}, \mathrm{Mcal} / \mathrm{kg}$ & 2.20 \\
NE, Mcal/kg & 1.53 \\
CP & 13.7 \\
CP from NPN & 3.0 \\
Fat & 6.4 \\
Calcium & 0.73 \\
Phosphorus & 0.30 \\
Potassium & 0.75 \\
Additives & \\
Monensin, mg/kg & 28.6 or 36.3 \\
Tylosin, mg/kg & 9.9 \\
Vitamin A, IU/kg & 3,850 \\
Vitamin D, IU/kg & 390 \\
\hline
\end{tabular}

${ }^{a}$ Mixture of steam-flaked corn (86\%) and steam-flaked wheat (14\%) in Exp. 1 and 100\% steam-flaked corn in Exp. 2.

${ }^{\mathrm{b}}$ Contained $77 \%$ chopped alfalfa hay and $23 \%$ corn silage in Exp. 1 and $100 \%$ chopped alfalfa hay in Exp. 2.

$0.18 \mathrm{~kg} /$ animal. If a bunk score of 1 was recorded at 0000 , feed amounts were increased by $0.09 \mathrm{~kg} / \mathrm{animal}$. If a bunk score of $>1$ was recorded at 0600 , feed amounts were decreased by the estimated amount remaining in the bunk.

Feed calls for the clean bunk approach were adjusted based on visual observations at 2000, 2200, 0000, and 0600. If a bunk score of 1 or 2 was recorded at 2000 , feed amounts were increased 0.18 or $0.09 \mathrm{~kg} / \mathrm{animal}$, respectively. If a bunk score of 2 or greater was recorded at 2200 , feed amounts were reduced by 0.05 or $0.14 \mathrm{~kg} /$ animal, respectively. If a bunk score greater than 1 was recorded at 0600 , feed amounts were decreased by the estimated amount remaining in the bunk.

\section{Metabolism Experiment}

Eight ruminally fistulated steers were used in two concurrent $4 \times 4$ Latin squares to evaluate the effects of bunk management systems and monensin supplementation strategy on feeding behavior and ruminal fermentation. Rumen fistulizations and postsurgical care followed procedures outlined by Stock et al. (1991). Steers were maintained in a temperature-controlled room $\left(25^{\circ} \mathrm{C}\right)$ with ad libitum access to water. Each Latin square consisted of four steers fed by the same bunk management system (traditional ad libitum or clean bunk) throughout the experiment. Over an 18-d period, steers were stepped up to a finishing diet comprised of
Table 2. Average composition of finishing diet used in metabolism experiment evaluating monensin concentration and bunk management strategy (DM basis)

\begin{tabular}{|c|c|}
\hline Ingredient & $\%$ of dietary DM \\
\hline High-moisture corn & 42.25 \\
\hline Dry-rolled corn & 42.25 \\
\hline Ground alfalfa hay & 7.5 \\
\hline Molasses & 3.0 \\
\hline Dry, meal supplement ${ }^{\mathrm{a}}$ & 5.0 \\
\hline Limestone & 1.36 \\
\hline Urea & 0.58 \\
\hline Salt & 0.30 \\
\hline Ammonium sulfate & 0.25 \\
\hline Potassium chloride & 0.17 \\
\hline Dicalcium phosphate & 0.13 \\
\hline Trace mineral premix ${ }^{b}$ & 0.020 \\
\hline Vitamin premix ${ }^{\mathrm{c}}$ & 0.015 \\
\hline Tylosin premix ${ }^{\mathrm{d}}$ & 0.013 \\
\hline Monensin premix ${ }^{\mathrm{e}}$ & variable \\
\hline
\end{tabular}

${ }^{\text {as }}$ upplement fed at $5 \%$ of diet DM with fine ground corn as a carrier. All other supplement ingredients are listed as \% of diet DM.

${ }^{\mathrm{b}}$ Premix contained $10 \% \mathrm{Mg}, 6 \% \mathrm{Zn}, 4.5 \% \mathrm{Fe}, 2 \% \mathrm{Mn}, 0.5 \% \mathrm{Cu}, 0.3 \%$ I, $0.05 \%$ Co.

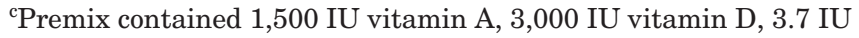
vitamin E per gram.

${ }^{\mathrm{d}}$ Premix contained $88 \mathrm{~g} / \mathrm{kg}$ tylosin to provide $5 \mathrm{mg} / \mathrm{kg}$ of DM.

ePremix contained $176 \mathrm{~g} / \mathrm{kg}$ monensin to supply either $0,36.7$, or $48.9 \mathrm{mg} / \mathrm{kg}$ of DM depending on treatment.

a 50:50 ratio of high-moisture:dry-rolled corn, alfalfa hay, and a milled supplement (Table 2). Steers were adapted to the grain by feeding diets containing 45,35 , 25 , and $15 \%$ forage (DM Basis) for 5, 3, 4, and $5 \mathrm{~d}$, respectively. Once on the final diet, steers were allowed $10 \mathrm{~d}$ of adaptation before the beginning of the first experimental period.

Steers in each Latin square were fed using a traditional, ad libitum (ADLIB) system or a clean bunk management system (CB), with feed delivered once daily at 0800 . Steers fed using the traditional bunk management system were fed to have 0.11 to $0.23 \mathrm{~kg}$ of feed remaining in the feed bunk at 0700 each day (ADLIB), whereas steers in the clean bunk system were fed to have access to feed from 0800 to 2200 . Feed calls for steers managed using the clean bunk system were based on the amount of feed remaining in the feed bunk at $2000,2100,2200$, and 0700 . The amount of feed remaining in the feed bunk at 2000, 2100, and 2200 was obtained from the computer used to capture, at 1min intervals, feed remaining in the bunk. If more than $0.23 \mathrm{~kg}$ of feed remained in the bunk at 2200, feed amounts were decreased by the estimated amount. If $0.23 \mathrm{~kg}$ or less feed remained in the bunk at 2200, feed calls were reduced by $0.23 \mathrm{~kg}$. If all feed was consumed before 2000, feed amounts were increased by $0.45 \mathrm{~kg}$, and, if all feed was consumed between 2100 and 2200 for two continuous days, feed amounts were increased by $0.23 \mathrm{~kg}$. Orts were taken each morning before feeding, weighed, and subsampled for DM determination. 
The metabolism study was a $2 \times 4$ factorial arrangement of treatments with bunk management (clean bunk vs traditional ad libitum intake) and four monensin treatments. Bunk management treatment was applied to replicates of the Latin square. Steers within each Latin square were assigned randomly to one of four monensin supplementation strategies. Dietary concentrations of monensin evaluated were as follows: 1) 0 (CON); 2) $36.7 \mathrm{mg} / \mathrm{kg}$ monensin, which equates to 33.3 g/ton (DM basis) fed continuously throughout each experimental period $(\mathbf{3 3})$; 3) $36.7 \mathrm{mg} / \mathrm{kg}$ fed prechallenge and changing to $48.9 \mathrm{mg} / \mathrm{kg}$, which equates to $44.4 \mathrm{~g} /$ ton (DM basis) on the challenge day and fed throughout the recovery phase $(\mathbf{3 3 / 4 4})$; and 4) $48.9 \mathrm{mg} / \mathrm{kg}$ (44) fed continuously for each experimental period.

Experimental periods were $35 \mathrm{~d}$ in length, during which time feed intake was monitored continuously using a data acquisition system as described by Cooper et al. (1999). Days 11 to 14 were a dietary adaptation period with steers housed in free stalls $(1.5 \times 2.4 \mathrm{~m})$. On d 15, steers were moved to tie stalls and tethered. Feed intake was monitored continuously with bunks suspended from load cells (Omega, Stamford, CT). Ruminal $\mathrm{pH}$ also was continuously monitored with submersible $\mathrm{pH}$ probes (Sensorex, Stanton, CA) fitted through the cannula and suspended in rumen fluid. During each collection period in stalls, feed bunk weights and ruminal $\mathrm{pH}$ data were collected with software (Labtech, Wilmington, MA), reading every $6 \mathrm{~s}$ and averaging data across every 2 min (720 measurements/ d). Ruminal $\mathrm{pH}$ was monitored continuously from d 15 through 35 for each period. Days 24 through 30 were a prechallenge phase in which steers were fed to appetite according the bunk management system imposed. On d 31 , steers were challenged by feeding $125 \%$ of the previous day's feed intake, $4 \mathrm{~h}$ late (1200). Days 32 through 35 were a challenge recovery period. On d 32 , steers were fed the same amount of feed as on $d 30$. On d 33 through 35 , steers were fed to appetite based on the bunk management system. Between periods, steers being placed on CON were inoculated with $2 \mathrm{~L}$ of rumen fluid from another steer fed no monensin.

Measures of feed intake included DMI per day, rate of feed intake calculated as described by Cooper et al. (1999), number of meals per day, total time spent eating per day, average meal size, and average time spent eating a meal. Meals were determined when feed bunk weights did not change for $20 \mathrm{~min}$, as is similar to Cooper et al. (1999). Previous researchers (Gibb et al., 1998; Schwartzkopf-Genswein et al., 2002) evaluating bunk visits as meals have used 5 min as an interval to establish breaks in meals. With continuous weights on bunks, bunk weights need to remain constant to avoid confounding when steers are moving bunks but not removing feed. Rate of feed intake was considered to be a function of first-order kinetics and, therefore, was calculated as the slope through the natural log transformation of feed weights for each steer throughout each day, with the units of percent per hour. Cooper et al.
(1999) used linear and quadratic functions to describe intake patterns. Clearly, a quadratic relationship exists for rate of feed intake and is a better fit based on $\mathrm{r}^{2}$. A total of 720 feed intake measurements were taken daily (one measurement/2 min). Ruminal metabolism measurements included average ruminal $\mathrm{pH}$, maximum and minimum ruminal $\mathrm{pH}$, ruminal $\mathrm{pH}$ change (maximum minus minimum), ruminal $\mathrm{pH}$ variance, and ruminal $\mathrm{pH}$ area below 5.6. Average ruminal $\mathrm{pH}$ was calculated as the average of 720 measurements recorded daily. Ruminal $\mathrm{pH}$ variance and area below 5.6 were calculated as described by Cooper et al. (1999).

The University of Nebraska Institutional Animal Care and Use Committee reviewed and approved all procedures used in these experiments (IACUC \#9804-021).

In Exp. 1 and 2, data were analyzed using the GLM procedure of SAS (SAS Inst. Inc., Cary, NC) for a complete block design with pen as the experimental unit. Block was pen replicate, with pens assigned to treatment within six blocks of three pens each. The model included treatment, pen replicate, and treatment $\times$ replicate (experimental error). Orthogonal contrasts were used to compare 1) traditional vs. the average of the clean bunk management treatments and 2) monensin effects within clean bunk management, with monensin at $28.6 \mathrm{mg} / \mathrm{kg}$ vs. $36.3 \mathrm{mg} / \mathrm{kg}$ (DM basis).

In the metabolism experiment, statistical analyzes were conducted using the mixed procedure of SAS (SAS Inst. Inc.) for a replicated Latin square. Model included period and rumensin treatment, with steer (experimental unit) as a random effect. Data were analyzed in three phases: 1) prechallenge, 2) challenge, and 3) postchallenge. Contrasts were used in the prechallenge phase to compare CON to the average of the treatments containing monensin, and 33 vs. $44 \mathrm{~g} / \mathrm{t}$ monensin. Contrasts were used in the challenge and postchallenge phases to compare CON vs. the average of the treatments containing monensin, 33 vs. $33 / 44$, and 44 vs. $33 / 44$ treatments.

\section{Results and Discussion}

\section{Feedlot Performance}

Weekly mean bunk scores are summarized in Table 3. In both Exp. 1 and Exp. 2, consumption patterns were altered by the imposed bunk management treatments. Steers fed using the traditional ad libitum bunk management treatment had higher $(P<0.001)$ mean bunk scores at 2000, 2200, and 0000 compared with those fed using clean bunk management. By 0600, mean bunk scores were similar $(P>0.10)$ between traditional and clean bunk management treatments. Feed bunks were targeted to be empty of feed (Bunk Score 1) by 2200 in both experiments for the clean bunk treatments. Approximately $60 \%$ of the bunks were empty of feed by 2200. However, cattle fed using clean bunk management had longer exposure to feed in Exp. 1 compared 
Table 3. Summary of weekly mean bunk scores by time and treatment for Experiments 1 and 2 evaluating traditional ad libitum (ADLIB) or clean bunk management (CB) ${ }^{\mathrm{a}}$

\begin{tabular}{|c|c|c|c|c|c|}
\hline \multirow[b]{2}{*}{ Item } & \multirow{2}{*}{$\begin{array}{l}\text { Bunk } \\
\text { management }^{\mathrm{b}}\end{array}$} & \multicolumn{4}{|c|}{ Time, h } \\
\hline & & 2000 & 2200 & 0000 & 0600 \\
\hline \multirow[t]{2}{*}{ Target score } & ADLIB & 5 & 2 & 2 & 1 \\
\hline & $\mathrm{CB}$ & $3-4$ & 1 & 1 & 1 \\
\hline \multicolumn{6}{|l|}{ Exp. $1^{\mathrm{c}}$} \\
\hline \multirow{6}{*}{$\begin{array}{l}\text { No. of observations } \\
\text { Average bunk score }\end{array}$} & & 144 & 144 & 144 & 144 \\
\hline & & & & & \\
\hline & ADLIB-26 & $3.7^{\mathrm{d}}$ & $2.4^{\mathrm{d}}$ & $2.2^{\mathrm{d}}$ & $1.5^{\mathrm{d}}$ \\
\hline & CB-26 & $2.9^{\mathrm{e}}$ & $1.7^{\mathrm{e}}$ & $1.5^{\mathrm{e}}$ & $1.2^{\mathrm{e}}$ \\
\hline & CB-33 & $3.0^{\mathrm{e}}$ & $1.6^{\mathrm{e}}$ & $1.5^{\mathrm{e}}$ & $1.2^{\mathrm{e}}$ \\
\hline & SEM & 0.05 & 0.06 & 0.05 & 0.01 \\
\hline \multicolumn{6}{|c|}{ Percentage of bunk scores $>1$} \\
\hline & ADLIB-26 & $97^{\mathrm{d}}$ & $75^{\mathrm{d}}$ & $66^{\mathrm{d}}$ & $38^{\mathrm{d}}$ \\
\hline & CB-26 & $85^{\mathrm{e}}$ & $42^{\mathrm{e}}$ & $32^{\mathrm{e}}$ & $15^{\mathrm{e}}$ \\
\hline & CB-33 & $87^{\mathrm{e}}$ & $39^{\mathrm{e}}$ & $31^{\mathrm{e}}$ & $15^{\mathrm{e}}$ \\
\hline & SEM & 1 & 3 & 2 & 1 \\
\hline \multicolumn{6}{|l|}{ Exp. $2^{\mathrm{c}}$} \\
\hline \multirow{2}{*}{\multicolumn{6}{|c|}{ Average bunk score }} \\
\hline & & & & & \\
\hline & ADLIB-26 & $2.9^{\mathrm{d}}$ & $2.5^{\mathrm{d}}$ & $2.0^{\mathrm{d}}$ & $1.5^{\mathrm{d}}$ \\
\hline & CB-26 & $2.0^{\mathrm{e}}$ & $1.7^{\mathrm{e}}$ & $1.5^{\mathrm{e}}$ & $1.2^{\mathrm{e}}$ \\
\hline & CB-33 & $2.1^{\mathrm{e}}$ & $1.8^{\mathrm{e}}$ & $1.5^{\mathrm{e}}$ & $1.2^{\mathrm{e}}$ \\
\hline & SEM & 0.04 & 0.03 & 0.03 & 0.02 \\
\hline \multicolumn{6}{|c|}{ Percentage of bunk scores $>1$} \\
\hline & ADLIB-26 & $80^{\mathrm{d}}$ & $73^{\mathrm{d}}$ & $59^{\mathrm{d}}$ & $34^{\mathrm{d}}$ \\
\hline & CB-26 & $54^{\mathrm{ef}}$ & $42^{\mathrm{ef}}$ & $32^{\mathrm{e}}$ & $14^{\mathrm{e}}$ \\
\hline & CB-33 & $59^{\mathrm{eg}}$ & $46^{\mathrm{eg}}$ & $32^{\mathrm{e}}$ & $14^{\mathrm{e}}$ \\
\hline & SEM & 2 & 2 & 2 & 1 \\
\hline
\end{tabular}

\footnotetext{
a 1 = slick, no residual crumbs or fines; $2=$ minimal amount of residual crumbs or fines, $<11 \mathrm{~kg} ; 3=$ small amount of residual feed, 11 to $27 \mathrm{~kg} ; 4$ = moderate amount residual feed, 27 to $45 \mathrm{~kg}$; 5 = large amount of residual feed, $>45 \mathrm{~kg}$.

${ }^{\mathrm{b}}$ ADLIB-26 = traditional bunk management system with monensin fed at $28.6 \mathrm{mg} / \mathrm{kg}$ (DM basis); CB-26 and $\mathrm{CB}-33$ = clean bunk management system with monensin fed at 28.6 and $36.3 \mathrm{mg} / \mathrm{kg}$ (DM basis), respectively.

${ }^{\mathrm{c}} F$-test statistic was significant $(P<0.001)$ for treatment for all bunk scores within time.

${ }^{\mathrm{d}, \mathrm{e}}$ Means with different superscripts within a time (column) for individual variables are different $(P<$ $0.001)$.

${ }_{\text {f,g Means with different superscripts within a time (column) for individual variables are different }(P<}$ $0.10)$.
}

with Exp. 2. In Exp. 2, approximately $45 \%$ of the bunks were given a bunk score of 1 at 2000 compared with only 12 to $13 \%$ of the bunks receiving a bunk score of 1 at 2000 in Exp. 1.

Animal performance is presented in Tables 4 and 5 for steers in Exp. 1 and Exp. 2, respectively. In Exp. 1, finishing performance was similar between steers fed using the clean or traditional bunk management treatments. Steers fed CB-33 gained faster $(P<0.03)$ than those fed CB-26 due to increased monensin concentration. Additionally, steers fed CB-33 tended $(P<0.08$; $F$-test $P<0.16)$ to gain more efficiently than those fed CB-26. Total and digestive death losses were similar among treatments.

In Exp. 2, steers fed using traditional bunk management had greater DMI $(P<0.01)$ and $\mathrm{ADG}(\mathrm{P}<0.02$, live basis; $P<0.01$, carcass-adjusted basis) than steers fed using clean bunk management. Performance was similar when steers were fed either CB-26 or CB-33. Total and digestive death losses were similar among treatments. Feed efficiency was not markedly influenced when monensin was increased from 28.6 to 36.3 $\mathrm{mg} / \mathrm{kg}$ (DM basis) in these experiments. Goodrich et al. (1984) summarized the performance data from 16,000 cattle, and feeding monensin improved feed efficiency by $7.5 \%$ compared to no monensin. However, based on that summary, performance was not improved when monensin intakes increased above $250 \mathrm{mg}$ per steer. The response to monensin also tends to be decreased as the energy density of the diet increases (Goodrich et al., 1984). Stock et al. (1995) evaluated 0,22 , or 33 $\mathrm{mg} / \mathrm{kg}$ in four commercial feedlot experiments. Feeding monensin improved feed efficiency by $4 \%$; however, no differences were detected between 22 and $33 \mathrm{mg} / \mathrm{kg}$ monensin treatments.

Differences in the performance response between the bunk management treatments in Exp. 1 vs. Exp. 2 are probably related to differences in exposure time to feed. In Exp. 1, a greater percentage of pens had feed remaining in the bunk at 2000 compared with Exp. 2. 
Table 4. Effect of bunk management and monensin concentration on performance of finishing steers in Experiment 1, commercial research conducted during the summer

\begin{tabular}{|c|c|c|c|c|c|c|}
\hline \multirow[b]{3}{*}{ Item } & \multicolumn{3}{|c|}{ Treatment $^{\mathrm{a}}$} & \multirow[b]{3}{*}{ SEM } & \multicolumn{2}{|c|}{ Probability ${ }^{\mathrm{b}}$} \\
\hline & & & & & \multirow{2}{*}{$\begin{array}{l}\text { Bunk } \\
\text { management }\end{array}$} & \multirow[b]{2}{*}{ Monensin } \\
\hline & ADLIB-26 & CB-26 & CB-33 & & & \\
\hline Pens, $\mathrm{n}$ & 6 & 6 & 6 & & & \\
\hline No. of steers & 602 & 599 & 592 & & & \\
\hline Total mortality, $\mathrm{n}$ & 4 & 4 & 3 & & & \\
\hline No. of digestive deaths & 1 & 3 & 1 & & & \\
\hline No. of removals ${ }^{\mathrm{c}}$ & 5 & 6 & 4 & & & \\
\hline \multicolumn{7}{|l|}{ Live performance $^{\mathrm{d}}$} \\
\hline Initial BW, kg & 260 & 261 & 261 & 1 & 0.33 & 0.76 \\
\hline Final BW, kg & 504 & 502 & 508 & 2 & 0.87 & 0.08 \\
\hline $\mathrm{DMI}, \mathrm{kg} / \mathrm{d}$ & 7.81 & 7.71 & 7.76 & 0.06 & 0.30 & 0.55 \\
\hline $\mathrm{ADG}, \mathrm{kg} / \mathrm{d}$ & 1.31 & 1.28 & 1.32 & 0.01 & 0.68 & 0.03 \\
\hline ADG/DMI & 0.167 & 0.167 & 0.170 & 0.001 & 0.47 & 0.08 \\
\hline \multicolumn{7}{|c|}{ Carcass-adjusted performance $\mathrm{e}^{\mathrm{e}}$} \\
\hline Final BW, kg & 504 & 503 & 507 & 3 & 0.83 & 0.41 \\
\hline $\mathrm{ADG}, \mathrm{kg}$ & 1.31 & 1.29 & 1.32 & 0.01 & 0.83 & 0.34 \\
\hline ADG/DMI & 0.167 & 0.168 & 0.169 & 0.001 & 0.47 & 0.62 \\
\hline
\end{tabular}

The clean bunk management treatment appeared to limit DMI in Exp. 2 and had little impact on DMI in Exp. 1. These different responses in DMI between Exp.
1 and Exp. 2 demonstrate the importance of the target slick (clean) times in a clean bunk management strategy. The different effect on DMI between Exp. 1 and

Table 5. Effect of bunk management and monensin concentration on performance of finishing steers in Exp. 2, commercial research conducted during the winter months

\begin{tabular}{|c|c|c|c|c|c|c|}
\hline \multirow[b]{3}{*}{ Item } & \multirow{2}{*}{\multicolumn{3}{|c|}{ Treatment $^{\mathrm{a}}$}} & \multirow[b]{3}{*}{ SEM } & \multicolumn{2}{|c|}{ Probability $^{\mathrm{b}}$} \\
\hline & & & & & \multirow{2}{*}{$\begin{array}{l}\text { Bunk } \\
\text { management }\end{array}$} & \multirow[b]{2}{*}{ Monensin } \\
\hline & ADLIB-26 & CB-26 & CB-33 & & & \\
\hline Pens, n & 6 & 6 & 6 & & & \\
\hline No. of steers & 542 & 538 & 535 & & & \\
\hline Total mortality, $\mathrm{n}$ & 1 & 0 & 2 & & & \\
\hline No. of digestive deaths & 0 & 0 & 2 & & & \\
\hline No. of removals ${ }^{c}$ & 2 & 4 & 0 & & & \\
\hline \multicolumn{7}{|l|}{ Live performance $^{\mathrm{d}}$} \\
\hline Initial BW, kg & 298 & 300 & 299 & 1 & 0.57 & 0.59 \\
\hline Final BW, kg & 556 & 548 & 547 & 3 & 0.02 & 0.82 \\
\hline DMI, kg/d & 8.83 & 8.58 & 8.51 & 0.07 & 0.01 & 0.48 \\
\hline $\mathrm{ADG}, \mathrm{kg} / \mathrm{d}$ & 1.53 & 1.47 & 1.47 & 0.02 & 0.02 & 0.96 \\
\hline ADG/DMI & 0.173 & 0.171 & 0.173 & 0.001 & 0.37 & 0.34 \\
\hline \multicolumn{7}{|c|}{ Carcass-adjusted performance $\mathrm{e}^{\mathrm{e}}$} \\
\hline Final BW, kg & 557 & 547 & 547 & 2 & 0.01 & 0.99 \\
\hline $\mathrm{ADG}, \mathrm{kg}$ & 1.53 & 1.46 & 1.47 & 0.02 & $<0.01$ & 0.77 \\
\hline ADG/DMI & 0.174 & 0.170 & 0.173 & 0.001 & 0.13 & 0.20 \\
\hline
\end{tabular}

${ }^{\mathrm{a}} \mathrm{ADLIB}-26$ = traditional bunk management system with monensin fed at $28.6 \mathrm{mg} / \mathrm{kg}$; CB-26 and CB-33 = clean bunk management system with monensin fed at 28.6 and $36.3 \mathrm{mg} / \mathrm{kg}$ (DM basis), respectively.

${ }^{\mathrm{b}} F$-test $=$ overall treatment $F$-test; Bunk management $=$ traditional vs. clean bunk management for monensin concentrations of $28.6 \mathrm{mg} / \mathrm{kg}$; Monensin = comparison of 28.6 and $36.3 \mathrm{mg} / \mathrm{kg}$ monensin within clean bunk management.

cAnimals removed from trial because of chronic disease or injury.

${ }^{\mathrm{d}}$ Final BW measured live and pencil shrunk $4 \%$.

${ }^{e}$ Final BW calculated from hot carcass weight divided by the average dressing percent of all treatments. 
Table 6. Effect of bunk management and monensin concentration on carcass characteristics of finishing steers in Exp. 1

\begin{tabular}{|c|c|c|c|c|c|c|}
\hline \multirow[b]{3}{*}{ Item } & \multirow{2}{*}{\multicolumn{3}{|c|}{ Treatment $^{\mathrm{a}}$}} & \multirow[b]{3}{*}{ SEM } & \multicolumn{2}{|c|}{ Probability $^{\mathrm{b}}$} \\
\hline & & & & & \multirow{2}{*}{$\begin{array}{l}\text { Bunk } \\
\text { management }\end{array}$} & \multirow[b]{2}{*}{ Monensin } \\
\hline & ADLIB-26 & CB-26 & CB-33 & & & \\
\hline Pens, $\mathrm{n}$ & 6 & 6 & 6 & & & \\
\hline Carcasses, $\mathrm{n}$ & 590 & 586 & 584 & & & \\
\hline Carcass weight, $\mathrm{kg}$ & 326 & 326 & 328 & 1.9 & 0.81 & 0.42 \\
\hline Dressing percent & 64.7 & 64.9 & 64.5 & 0.09 & 0.74 & 0.01 \\
\hline \multicolumn{7}{|c|}{ USDA quality grade, $\%$} \\
\hline Prime & 1.1 & 0.6 & 1.7 & 1.7 & 0.91 & 0.27 \\
\hline Choice & 61.8 & 56.0 & 56.2 & 1.3 & $<0.01$ & 0.78 \\
\hline Select & 34.8 & 40.5 & 39.6 & 1.6 & 0.03 & 0.71 \\
\hline No roll & 2.3 & 2.9 & 2.5 & 0.6 & 0.64 & 0.59 \\
\hline \multicolumn{7}{|l|}{ USDA yield grade, $\%$} \\
\hline 1 & 12.8 & 15.5 & 12.5 & 0.7 & 0.21 & 0.02 \\
\hline 2 & 51.6 & 53.8 & 49.8 & 2.9 & 0.97 & 0.35 \\
\hline 3 & 33.9 & 29.8 & 36.4 & 3.2 & 0.83 & 0.16 \\
\hline 4 and 5 & 1.7 & 0.9 & 1.3 & 0.6 & 0.43 & 0.60 \\
\hline Liver abscesses, $\%$ & 12.1 & 11.7 & 8.5 & 1.9 & 0.42 & 0.25 \\
\hline
\end{tabular}

${ }^{\mathrm{a}} \mathrm{ADLIB}-26$ = traditional bunk management system with monensin fed at $28.6 \mathrm{mg} / \mathrm{kg}$; CB-26 and CB-33 $=$ clean bunk management system with monensin fed at 28.6 and $36.3 \mathrm{mg} / \mathrm{kg}$ (DM basis), respectively.

${ }^{\mathrm{b}} F$-test $=$ overall treatment $F$-test; Bunk management $=$ traditional vs. clean bunk management for monensin concentrations of $28.6 \mathrm{mg} / \mathrm{kg}$; Monensin = comparison of 28.6 and $36.3 \mathrm{mg} / \mathrm{kg}$ monensin within clean bunk management.

Exp. 2 may also suggest that the time of year influences target clean time. Experiment 1 was conducted from April to November, whereas Exp. 2 was conducted from November to April.

Carcass characteristics are presented in Tables 6 and 7 for Exp. 1 and Exp. 2, respectively. In Exp. 1 , hot carcass weight was similar among treatments. However, in Exp. 2 carcass weights were heavier $(P<$
0.01) for steers fed using the traditional compared with the clean bunk management treatment. Differences in carcass weight in Exp. 2 reflect differences in ADG. In both Exp. 1 and Exp. 2, steers fed using the traditional bunk management treatment had a greater $(P<0.01$, Exp. 1; $P<0.02$, Exp. 2) percentage of carcasses grading USDA Choice compared with the clean bunk management treatment. Changes in USDA quality grade

Table 7. Effect of bunk management and monensin concentration on carcass characteristics of finishing steers in Exp. 2

\begin{tabular}{|c|c|c|c|c|c|c|}
\hline \multirow[b]{3}{*}{ Item } & \multirow{2}{*}{\multicolumn{3}{|c|}{ Treatment $^{\mathrm{a}}$}} & \multirow[b]{3}{*}{ SEM } & \multicolumn{2}{|c|}{ Probability $^{\mathrm{b}}$} \\
\hline & & & & & \multirow{2}{*}{$\begin{array}{l}\text { Bunk } \\
\text { management }\end{array}$} & \multirow[b]{2}{*}{ Monensin } \\
\hline & ADLIB-26 & CB-26 & CB-33 & & & \\
\hline Pens, $\mathrm{n}$ & 6 & 6 & 6 & & & \\
\hline Carcasses, $\mathrm{n}$ & 539 & 534 & 531 & & & \\
\hline Carcass weight, $\mathrm{kg}$ & 361 & 354 & 354 & 1.6 & 0.01 & 0.99 \\
\hline Dressing percent & 64.9 & 64.6 & 64.7 & 0.12 & 0.29 & 0.55 \\
\hline \multicolumn{7}{|c|}{ USDA quality grade, $\%$} \\
\hline Prime & 2.5 & 1.1 & 2.4 & 0.6 & 0.33 & 0.15 \\
\hline Choice & 70.7 & 66.8 & 58.3 & 2.3 & 0.02 & 0.03 \\
\hline Select & 25.2 & 30.4 & 36.0 & 2.1 & 0.01 & 0.09 \\
\hline No roll & 1.5 & 1.7 & 2.6 & 0.6 & 0.37 & 0.26 \\
\hline \multicolumn{7}{|l|}{ USDA yield grade, $\%$} \\
\hline 1 & 22.3 & 19.9 & 22.7 & 2.5 & 0.74 & 0.45 \\
\hline 2 & 49.0 & 57.2 & 48.6 & 2.8 & 0.28 & 0.06 \\
\hline 3 & 28.3 & 22.5 & 28.2 & 1.7 & 0.20 & 0.05 \\
\hline 4 and 5 & 0.4 & 0.4 & 0.5 & 0.3 & 0.86 & 0.75 \\
\hline Liver abscesses, $\%$ & 5.2 & 6.0 & 7.0 & 1.1 & 0.35 & 0.52 \\
\hline
\end{tabular}

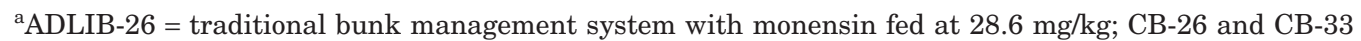
= clean bunk management system with monensin fed at 28.6 and $36.3 \mathrm{mg} / \mathrm{kg}$ (DM basis), respectively.

${ }^{\mathrm{b}} F$-test $=$ overall treatment $F$-test; Bunk management $=$ traditional vs. clean bunk management for monensin concentrations of $28.6 \mathrm{mg} / \mathrm{kg}$; Monensin = comparison of 28.6 and $36.3 \mathrm{mg} / \mathrm{kg}$ monensin within clean bunk management. 
are most likely a reflection of DMI between the bunk management strategies. Dry matter intake was significantly increased in Exp. 2 and was numerically greater in Exp. 1 for the traditional vs. clean bunk management treatments. The incidence of liver abscesses was similar between bunk management and dietary monensin concentration for both Exp. 1 and Exp. 2.

\section{Metabolism Experiment}

Prechallenge Phase. Results of the prechallenge phase of the metabolism experiment are presented in Table 8 . No interactions between monensin supplementation strategy and bunk management system were observed; therefore, main effects of monensin supplementation strategy and bunk management system are reported. Feeding monensin reduced $(P<0.05)$ average meal size and average meal length compared with control. Dry matter intake was similar among all treatments. The number of meals was fewer and the total time spent eating each meal was greater in our metabolism experiment compared with previous experiments (Hoffman and Self, 1973; Gonyou and Stricklin, 1984; Laudert, 1995). These previous experiments were conducted by observing and recording meal times with steers fed in commercial pens or small research pens. The steers in the present metabolism experiment were tethered in tie stalls with feed and water continually in close proximity. This arrangement may alter consumption patterns compared with open lots where cattle are exposed to various social and environmental conditions. Additionally, previous experiments have reported consumption patterns by visually observing cattle, whereas data in the present metabolism experiment were collected continuously with load cells and a computer.

In this experiment, cattle spent 500 to 530 min eating with 5.9 to 6.8 meals/d. Cooper et al. (1999), using similar techniques, observed 7.9 to 9.5 meals/d with a total eating time of 291 to $331 \mathrm{~min} / \mathrm{d}$ for cattle fed corn-based diets. Using the GrowSafe system (radio frequency technology) in Canada with pen fed steers, Gibb et al. (1998) observed a total of $30 \mathrm{~min}$ of eating time with 7.5 bunk visits (i.e., meals) per steer when fed a finishing (92\% concentrate) diet. In contrast, SchwartzkopfGenswein et al. (2002) evaluated six steers and six heifers and observed 15 to $18 \mathrm{meals} / \mathrm{d}$, with a total eating time of 95 to $131 \mathrm{~min} / \mathrm{d}$ per animal using the GrowSafe system. The cattle restricted to $95 \%$ of their ad libitum intake consumed fewer meals and spent less time eating. The data are variable from experiment to experiment. The metabolism experiment used tethered animals that are individually fed, which may influence feeding behavior.

Average ruminal $\mathrm{pH}, \mathrm{pH}$ change, and ruminal $\mathrm{pH}$ area $<5.6$ were similar between steers fed monensin and the control (Table 8). Monensin reduced $(P<0.05)$ ruminal $\mathrm{pH}$ variance during the pre-challenge phase.
Monensin appears to control daily fluctuations in ruminal $\mathrm{pH}$ under normal feeding conditions.

Dry matter intake was similar between bunk management systems during the prechallenge phase (Table 8). Steers fed using clean bunk management had a faster $(P<0.01)$ rate of intake, consumed fewer $(P<$ $0.01)$ meals/d, and had larger $(P<0.05)$ meal sizes compared with those fed using traditional bunk management. Additionally, steers fed using clean bunk management spent less $(P<0.04)$ time eating per day and more $(P<0.03)$ time eating per meal compared with those fed using traditional bunk management. The target clean-up time for steers in the metabolism experiment was between 2200 and 2400, similar to both feedlot performance experiments. One can assume that feeding patterns were similar between the animal performance experiments and the metabolism experiment. These data also demonstrate the impact that feeding management can have on the feeding patterns of finishing cattle.

Average ruminal $\mathrm{pH}, \mathrm{pH}$ change, and ruminal $\mathrm{pH}$ area $<5.6$ were similar between clean and traditional bunk management systems (Table 8 ). The daily variance in ruminal $\mathrm{pH}$ was greater $(P<0.01)$ for steers fed using clean bunk management compared with those fed using traditional bunk management. Feeding steers using clean bunk management did not increase the incidence of acidosis, as measured by ruminal $\mathrm{pH}$ area $<$ 5.6 and average ruminal $\mathrm{pH}$. Steers fed using clean bunk management consumed similar amounts of DM as traditional bunk management, but were without feed for approximately $10 \mathrm{~h}$. Ruminal $\mathrm{pH}$ was numerically higher at time of feeding for steers fed using clean bunk management (6.56 vs. 6.40) compared to traditional bunk management, but nonsignificant $(P>0.50)$. This time without exposure to feed may allow steers to build a buffering capacity and start at a higher ruminal $\mathrm{pH}$ prior to each feeding.

Challenge. Results from the challenge day are presented in Table 9. No interactions were observed during the challenge period between monensin supplementation strategy and bunk management system. Consumption patterns and ruminal $\mathrm{pH}$ measurements were similar among monensin supplementation strategies. $\mathrm{Ru}-$ minal $\mathrm{pH}$ change $(P<0.10)$ and ruminal $\mathrm{pH}$ variance $(P<0.01)$ were greater for steers fed using clean bunk compared with those fed using traditional bunk management. Average ruminal $\mathrm{pH}$ and ruminal $\mathrm{pH}$ area below 5.6 were similar between bunk management strategies. Steers fed using a clean bunk program consumed feed at a faster rate $(28 \%$ vs. $18 \% / h)$ than steers fed using a traditional ad libitum program. Although not significant, this led to a numerically greater meal size but numerically lower number of meals for cattle fed using the clean bunk management compared to the traditional. Based on the experimental design with feeding $4 \mathrm{~h}$ late, steers may start the feeding cycle at 1200 with a ruminal $\mathrm{pH}$ that is higher than previous days. The greater $\mathrm{pH}$ may allow that animal to compen- 
Table 8. Main effects of monensin supplementation and bunk management on intake, feeding behavior, and ruminal $\mathrm{pH}$ of steers fed finishing diets during

the prechallenge phase (metabolism experiment)

\begin{tabular}{|c|c|c|c|c|c|c|c|c|c|c|}
\hline \multirow[b]{2}{*}{ Item } & \multicolumn{6}{|c|}{ Monensin supplementation $^{\mathrm{a}}$} & \multicolumn{4}{|c|}{ Bunk management ${ }^{b}$} \\
\hline & $\mathrm{CON}$ & 33 & $33 / 44$ & 44 & SEM & $F$-test & $\mathrm{CBM}$ & ADLIB & SEM & $F$-test \\
\hline Observations, $\mathrm{n}$ & 8 & 8 & 8 & 8 & & & 16 & 16 & & \\
\hline \multicolumn{11}{|l|}{ Intake } \\
\hline DMI, kg/d & 12.7 & 12.4 & 12.8 & 11.9 & 0.7 & 0.47 & 12.3 & 12.6 & 1.0 & 0.85 \\
\hline Rate, $\% / \mathrm{h}$ & 26.7 & 23.3 & 25.4 & 26.3 & 2.1 & 0.69 & 32.3 & 18.5 & 1.5 & $<0.01$ \\
\hline Meals, number/d & 5.9 & 6.8 & 6.5 & 6.3 & 0.5 & 0.50 & 4.5 & 8.2 & 0.57 & $<0.01$ \\
\hline Meal size, $\mathrm{kg}^{\mathrm{c}}$ & 3.4 & 2.3 & 2.2 & 2.3 & 0.5 & 0.13 & 3.5 & 1.6 & 0.55 & 0.05 \\
\hline Time eating, min & 502 & 519 & 505 & 530 & 29 & 0.90 & 475 & 553 & 20 & 0.04 \\
\hline Meal length, $\min ^{c}$ & 124 & 91 & 87 & 99 & 14 & 0.10 & 130 & 70 & 16 & 0.03 \\
\hline \multicolumn{11}{|l|}{ Ruminal pH } \\
\hline Average & 5.69 & 5.64 & 5.81 & 5.73 & 0.11 & 0.37 & 5.75 & 5.69 & 0.14 & 0.77 \\
\hline Change & 1.47 & 1.39 & 1.36 & 1.34 & 0.09 & 0.61 & 1.46 & 1.31 & 0.08 & 0.23 \\
\hline Variance $^{\mathrm{c}}$ & 0.16 & 0.12 & 0.13 & 0.13 & 0.02 & 0.15 & 0.19 & 0.08 & 0.02 & $<0.01$ \\
\hline Area $<5.6^{\mathrm{d}}$ & 104 & 115 & 106 & 98 & 33 & 0.87 & 95 & 116 & 44 & 0.75 \\
\hline
\end{tabular}

${ }^{\mathrm{a}} \mathrm{CON}=0 \mathrm{mg} / \mathrm{kg}, 33=36.7 \mathrm{mg} / \mathrm{kg}, 33 / 44=36.7$ changed to $48.9 \mathrm{mg} / \mathrm{kg}$ the day of challenge, and $44=48.9$ $\mathrm{mg} / \mathrm{kg}$ monensin fed throughout.

${ }^{\mathrm{b}} \mathrm{CBM}=$ clean bunk management, $\mathrm{ADLIB}=$ traditional ad libitum bunk management.

${ }^{\mathrm{c} A v e r a g e}$ of all monensin treatments $(33,33 / 44$, and 44$)$ vs. CON differ $(P<0.05)$.

${ }^{\mathrm{d}}$ Area $=$ magnitude of ruminal $\mathrm{pH}$ below $5.6 \times$ minute.

sate for greater DMI (125\% of normal) and faster rates of intake. In this study, comparisons were not made across phases. However, ruminal $\mathrm{pH}$ was 6.6 initially on challenge days averaged across periods and only 6.48 during the prechallenge phase. Despite numerically higher initial $\mathrm{pH}$, the minimum $\mathrm{pH}$ was similar across treatments, bunk management, and phases, averaging a $\mathrm{pH}$ of 5.08. Similar to the prechallenge phase, initial $\mathrm{pH}$ was numerically greater for clean bunk management than traditional (6.71 vs. 6.51 ), but nonsignificant $(P>0.36)$. Cooper et al. (1999) suggested that the effect of ruminal $\mathrm{pH}$ on intake is at least partially dependent on the buffering capacity or $\mathrm{pH}$ of the ruminal contents at the beginning of a meal. In their experiment, intake was varied $\pm 1.8 \mathrm{~kg} / \mathrm{d}$. On days when cattle were overfed $1.8 \mathrm{~kg}$, ruminal $\mathrm{pH}$ at feeding was higher from being underfed $1.8 \mathrm{~kg}$ the previous day.

Postchallenge. Results of the postchallenge period are reported in Table 10. Dry matter intake, total time spent eating, and average meal length were similar across monensin supplementation strategies. The rate of DMI tended $(P<0.12)$ to be decreased for steers fed

Table 9. Main effects of monensin supplementation and bunk management on intake, feeding behavior, and ruminal $\mathrm{pH}$ of steers fed finishing diets during the challenge phase when steers were fed $125 \%$ of intake $2 \mathrm{~d}$ before and fed $4 \mathrm{~h}$ late (metabolism experiment)

\begin{tabular}{|c|c|c|c|c|c|c|c|c|c|c|}
\hline \multirow[b]{2}{*}{ Item } & \multicolumn{6}{|c|}{ Monensin supplementation $^{a}$} & \multicolumn{4}{|c|}{ Bunk management $^{\mathrm{b}}$} \\
\hline & $\mathrm{CON}$ & 33 & $33 / 44$ & 44 & SEM & $F$-test & $\mathrm{CBM}$ & ADLIB & SEM & $F$-test \\
\hline Observations, $\mathrm{n}$ & 8 & 8 & 8 & 8 & & & 16 & 16 & & \\
\hline \multicolumn{11}{|l|}{ Intake } \\
\hline DMI, kg/d & 15.2 & 14.3 & 15.4 & 14.2 & 1.0 & 0.20 & 15.4 & 14.1 & 1.3 & 0.52 \\
\hline Rate, $\% / \mathrm{h}$ & 22.6 & 22.4 & 20.2 & 24.6 & 2.4 & 0.66 & 27.1 & 17.9 & 1.7 & $<0.01$ \\
\hline Meals, number/d & 7.13 & 6.88 & 7.00 & 6.33 & 0.66 & 0.81 & 6.19 & 7.48 & 0.62 & 0.20 \\
\hline Meal size, kg & 2.39 & 2.41 & 2.36 & 2.36 & 0.40 & 0.99 & 2.76 & 2.00 & 0.48 & 0.30 \\
\hline Time eating, $\min$ & 502 & 510 & 537 & 523 & 29 & 0.80 & 521 & 515 & 20 & 0.86 \\
\hline Meal length, min & 76 & 82 & 81 & 88 & 10 & 0.81 & 90 & 73 & 11 & 0.29 \\
\hline \multicolumn{11}{|l|}{ Ruminal $\mathrm{pH}$} \\
\hline Average & 5.69 & 5.62 & 5.68 & 5.70 & 0.13 & 0.93 & 5.67 & 5.67 & 0.15 & 0.98 \\
\hline Change & 1.53 & 1.51 & 1.47 & 1.64 & 0.07 & 0.24 & 1.65 & 1.42 & 0.08 & 0.10 \\
\hline Variance & 0.21 & 0.18 & 0.18 & 0.22 & 0.03 & 0.48 & 0.27 & 0.13 & 0.03 & $<0.01$ \\
\hline Area $<5.6^{\mathrm{c}}$ & 131 & 139 & 151 & 119 & 43 & 0.89 & 135 & 134 & 49 & 0.99 \\
\hline
\end{tabular}

${ }^{\mathrm{a}} \mathrm{CON}=0 \mathrm{mg} / \mathrm{kg}, 33=36.7 \mathrm{mg} / \mathrm{kg}, 33 / 44=36.7$ changed to $48.9 \mathrm{mg} / \mathrm{kg}$ the day of challenge, and $44=48.9$ $\mathrm{mg} / \mathrm{kg}$ monensin fed throughout.

${ }^{\mathrm{b}} \mathrm{CBM}$ = clean bunk management, $\mathrm{ADLIB}=$ traditional ad libitum bunk management.

${ }^{\mathrm{c}}$ Area $=$ magnitude of rumen $\mathrm{pH}$ below $5.6 \times$ minutes. 
Table 10. Main effects of monensin supplementation and bunk management on intake, feeding behavior, and ruminal $\mathrm{pH}$ of steers fed finishing diets during the recovery phase (metabolism experiment)

\begin{tabular}{|c|c|c|c|c|c|c|c|c|c|c|}
\hline Item & \multicolumn{6}{|c|}{ Monensin supplementation $^{\mathrm{a}}$} & \multicolumn{4}{|c|}{ Bunk management ${ }^{b}$} \\
\hline Observations, $\mathrm{n}$ & 8 & 8 & 8 & 8 & & & 16 & 16 & & \\
\hline \multicolumn{11}{|l|}{ Intake } \\
\hline DMI, kg/d & 12.6 & 11.9 & 12.5 & 12.0 & 0.7 & 0.55 & 12.0 & 12.4 & 0.9 & 0.75 \\
\hline Rate, $\% / h^{c}$ & 27.0 & 24.6 & 21.0 & 24.3 & 1.9 & 0.22 & 30.2 & 18.2 & 1.9 & $<0.01$ \\
\hline Meals, number/d $\mathrm{d}^{\mathrm{d}}$ & 6.2 & 7.3 & 7.4 & 6.5 & 0.50 & 0.09 & 5.5 & 8.3 & 0.4 & $<0.01$ \\
\hline \multicolumn{11}{|l|}{ Ruminal pH } \\
\hline Average & 5.80 & 5.61 & 5.75 & 5.72 & 0.15 & 0.50 & 5.77 & 5.67 & 0.18 & 0.71 \\
\hline Area $<5.6^{\mathrm{e}}$ & 91 & 130 & 117 & 106 & 47 & 0.51 & 83 & 140 & 62 & 0.54 \\
\hline \multicolumn{11}{|c|}{ Variables with monensin $\times$ bunk management interaction $(P<0.10)$} \\
\hline \multicolumn{11}{|c|}{$\begin{array}{llllll}\text { No. of observations } & 4 & 4 & 4 & 4\end{array}$} \\
\hline ADLIB & 1.08 & 1.27 & 1.22 & 1.28 & & & & & & \\
\hline \multicolumn{11}{|l|}{ Ruminal $\mathrm{pH}$ variance } \\
\hline $\mathrm{CBM}^{\mathrm{f}}$ & 0.213 & 0.119 & 0.116 & 0.192 & 0.021 & & & & & \\
\hline ADLIB & 0.055 & 0.080 & 0.066 & 0.094 & & & & & & \\
\hline
\end{tabular}

${ }^{\mathrm{a}} \mathrm{CON}=0 \mathrm{mg} / \mathrm{kg}, 33=36.7 \mathrm{mg} / \mathrm{kg}, 33 / 44=36.7$ changed to $48.9 \mathrm{mg} / \mathrm{kg}$ the day of challenge, and $44=48.9 \mathrm{mg} / \mathrm{kg} \mathrm{monensin}$ fed throughout.

${ }^{\mathrm{b}} \mathrm{CBM}=$ clean bunk management, $\mathrm{ADLIB}=$ traditional ad libitum bunk management.

${ }^{\mathrm{c}}$ Average of all monensin treatments $(33,33 / 44$, and 44$)$ vs. CON $(\mathrm{P}<0.12)$.

${ }^{\mathrm{d}}$ Average of all monensin treatments $(33,33 / 44$, and 44$)$ vs. $\mathrm{CON}(\mathrm{P}<0.06)$.

${ }^{\mathrm{e}}$ Area $=$ magnitude of rumen $\mathrm{pH}$ below $5.6 \times$ minutes.

fAverage of all monensin treatments $(33,33 / 44$, and 44$)$ vs. CON $\operatorname{differ}(\mathrm{P}<0.10)$.

monensin compared with control. Steers fed monensin consumed a greater $(P<0.06)$ number of meals per day than those fed the control diet. Average ruminal $\mathrm{pH}$ and ruminal $\mathrm{pH}$ area $<5.6$ were similar across monensin supplementation strategies.

Interactions $(P<0.10)$ were observed between monensin supplementation strategy and bunk management system for average meal size, ruminal $\mathrm{pH}$ change, and ruminal $\mathrm{pH}$ variance (Table 10). Monensin decreased average meal size $(P<0.05)$, ruminal $\mathrm{pH}$ change $(P<0.10)$, and ruminal $\mathrm{pH}$ variance $(P<0.05)$ for steers fed using clean bunk management, whereas these measurements were similar between control and monensinsupplemented steers when fed using traditional bunk management.

Dry matter intake was similar between bunk management systems (Table 10); however, rate of intake was faster $(P<0.01)$ for steers fed using clean bunk compared with traditional bunk management. Similar to the intake patterns of the prechallenge period, steers fed using clean bunk management had fewer $(P<0.01)$ meals per day and the average time consuming each meal was less $(P<0.07)$ compared with those fed using traditional bunk management. Average ruminal $\mathrm{pH}$ and ruminal $\mathrm{pH}$ area below 5.6 were similar between bunk management systems.

On average, steers consumed $2.3 \mathrm{~kg}$ more DM the day of the intake challenge compared with their average DMI before the challenge. Additionally, steers con- sumed similar amounts of DM postchallenge compared with prechallenge. Our intake challenge may not have been severe enough to cause acute acidosis symptoms or effects on the animal. In this experiment, cattle fed using a clean bunk management system responded similarly to an intake challenge relative to those fed using a traditional bunk management system.

Differences in ruminal $\mathrm{pH}$ variance and feeding behavior indicated that monensin has a positive effect on controlling subacute acidosis under normal or challenged feeding conditions similar to previous experiments (Richardson et al., 1976; Burrin and Britton, 1986; Stock et al., 1995). Nagaraja et al. (1981) induced acidosis by direct infusion of glucose or corn, and monensin addition of approximately 450 to $500 \mathrm{mg} /$ animal maintained rumen $\mathrm{pH}$. Burrin and Britton (1986) evaluated 0,150 , or $300 \mathrm{mg}$ of monensin per animal; however, they challenged forage-fed animals with an abrupt diet change to concentrate. All animals in their experiment exhibited the characteristic decline in rumen $\mathrm{pH}$ from 6.5 to 5.5 , while monensin maintained a greater $\mathrm{pH}$ than control cattle (Burrin and Britton, 1986). Based on data with $\mathrm{pH}$ change and variance in the metabolism experiment, maintaining a more consistent rumen environment when monensin is fed may be more beneficial in clean bunk feeding programs compared with traditional programs.

Increasing monensin concentrations above currently approved levels within the bounds of this study seemed 
to have little effect. However, Laudert et al. (1994) and Vogel et al. (1999) both reported improved feed efficiency and a decrease in the incidence of digestive death loss when $48.9 \mathrm{mg} / \mathrm{kg}$ monensin (DM basis) was incorporated into the diets on calf-fed Holsteins.

\section{Implications}

Cattle gain and intakes are similar between clean and traditional bunk management programs if intakes of cattle on clean bunk management programs are not restricted. Clean-up time seems to be one of the most critical aspects of successful clean bunk management programs. Whether clean-up time is influenced by season, environment, or other factors is still unknown. Monensin minimizes subacute acidosis in feedlot cattle by manipulating the ruminal fermentation and feeding behavior of cattle fed high-grain finishing diets. Feeding monensin at concentrations greater than $36.7 \mathrm{mg} /$ $\mathrm{kg}$ (33 g/t, dry matter basis) had little effect on ruminal fermentation or feeding behavior with the level of intake challenge imposed in this experiment.

\section{Literature Cited}

Burrin, D. G., and R. A. Britton. 1986. Response to monensin in cattle during sub acute acidosis. J. Anim. Sci. 63:888-893.

Burrin, D. G., R. A. Stock, and R. A. Britton. 1988. Monensin level during grain adaptation and finishing performance in cattle. J. Anim. Sci. 66:513-521.

Cooper, R. J., T. J. Klopfenstein, R. A. Stock, C. T. Milton, D. W. Herold, and J. C. Parrott. 1999. Effects of imposed feed intake variation on acidosis and performance of finishing steers. J. Anim. Sci. 77:1093-1099.

Fulton, W. R., T. J. Klopfenstein, and R. A. Britton. 1979. Adaptation to high concentrate diets by beef cattle. 1. Adaptation to corn and wheat diets. J. Anim. Sci. 49:775-784.
Gibb, D. J., T. A. McAllister, C. Huisma, and R. D. Wiedmeier. 1998. Bunk attendance of feedlot cattle monitored with radio frequency technology. Can. J. Anim. Sci. 78:707-710.

Gonyou, H. W., and W. R. Stricklin. 1984. Diurnal behavior patterns of feedlot bulls during winter and spring in northern latitudes. J. Anim. Sci. 58:1075-1083.

Goodrich, R. D., J. E. Garrett, D. R. Gast, M. A. Kirick, D. A. Larson, and J. C. Meiske. 1984. Influence of monensin on the performance of cattle. J. Anim. Sci. 58:1484-1498.

Hoffman, M. P., and H. L. Self. 1973. Behavioral traits of feedlot steers in Iowa. J. Anim. Sci. 37:1438-1445.

Laudert, S. B. 1995. Feeding behavior of finishing steers. Pages 3135 in Symposium: Intake by Feedlot Cattle. P-942 Oklahoma Agr. Exp. Stn.

Laudert S. B., G. J. Vogel, J. C. Parrott, and D. R. White. 1994. The effect of two levels of Rumensin on feedlot performance of young Holstein steers fed to slaughter. J. Anim. Sci. 72(Suppl. 1):291.

Nagaraja, T. G., T. B. Avery, E. E. Bartley, S. J. Galitzer, and A. D. Dayton. 1981. Prevention of lactic acidosis in cattle by lasalocid or monensin. J. Anim. Sci. 53:206-216.

Pritchard, R. H., and K. W. Bruns. 2003. Controlling variation in feed intake through bunk management. J. Anim. Sci. 81(E. Suppl. 2):E133-E138. Online. Available http://www.asas.org/symposia/ 03esupp2/jas2395.pdf. Accessed August 22, 2003.

Richardson, L. F., A. P. Raun, E. L. Potter, C. O. Cooley, and R. P. Rathmacher. 1976. Effect of monensin on rumen fermentation in vitro and in vivo. J. Anim. Sci. 43:657-664.

Schwartzkopf-Genswein, K. S., S. Atwood, and T. A. McAllister. 2002. Relationships between bunk attendance, intake and performance of steers and heifers on varying feeding regimes. Appl. Anim. Behav. Sci. 76:179-188.

Stock, R. A., M. H. Sindt, J. C. Parrott, and F. K. Goedeken. 1990. Effects of grain type, roughage level and monensin level on finishing cattle performance. J. Anim. Sci. 68:3441-3455.

Stock, R. A., M. H. Sindt, R. M. Cleale, IV, and R. A. Britton. 1991. High-moisture corn utilization in finishing cattle. J. Anim. Sci. 69:1645-1656.

Stock, R. A., S. B. Laudert, W. W. Stroup, E. M. Larson, J. C. Parrott, and R. A. Britton. 1995. Effects of monensin and monensin and tylosin combinations on feed intake variation of feedlot steers. J. Anim. Sci. 73:39-44.

Vogel, G. J., J. C. Parrott, S. B. Laudert, and D. R. White. 1999. Effect of monensin level on feedlot performance of calf-fed Holstein steers fed to slaughter. J. Anim. Sci. 77(1):240. 